DOI: http://dx.doi.org/10.33846/hn40302

http://heanoti.com/index.php/hn

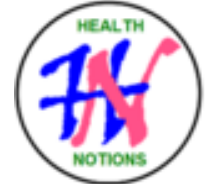

RESEARCH ARTICLE

URL of this article: http://heanoti.com/index.php/hn/article/view/hn40302

\title{
Family Support and Quality of Life in Breast Cancer Patients
}

\author{
Noorhidayah $^{1(\mathrm{CA})}$, Hesti Prawita Widiastuti ${ }^{2}$ Umi Kalsum ${ }^{3}$ \\ ${ }^{1(\mathrm{CA})}$ Department of Nursing, Poltekkes Kemenkes Kalimantan Timur, Indonesia; galuh.noorhidayah@gmail.com \\ (Corresponding Author) \\ ${ }^{2}$ Department of Nursing, Poltekkes Kemenkes Kalimantan Timur, Indonesia; hestiprawita@yahoo.com \\ ${ }^{3}$ Department of Nursing, Poltekkes Kemenkes Kalimantan Timur, Indonesia; umi2508@gmail.com
}

\begin{abstract}
Introduction: In these days, one of the terrifying cancers for women throughout the world is breast cancer. The treatment of cancer should be holistic. Patients need family support to create a good quality of life. The purpose of this study was to determine the relationship between family support and quality of life in breast cancer patients at the Chemotherapy Unit of Abdul Wahab Sjahranie Hospital Samarinda. Methods: Quantitative research with analytical study and cross-sectional design. Sampling was done with a total sample of 76 respondents. The instruments used in this research were family support standards and the Quality of Life Questionnaire-Core 30 (EORTC QLQ-C30) for quality of life. The data were analyzed using the Chi-Square test. Results: The p-value was 0.003 , OR $=4.090$, indicating that there was a relationship between family support and quality of life in breast cancer patients. Conclusion: There is a relationship between family support and quality of life in breast cancer patients. It is expected that the hospital can proceed in providing health education and motivation to breast cancer patients and their families related to the importance of family support for the quality of life of breast cancer patients.
\end{abstract}

Keywords: family support; breast cancer; quality of life

\section{INTRODUCTION}

\section{Background}

Cancer becomes the second high mortality cause in the world and it contributes to a mortality rate of 8.8 million in 2015. ${ }^{(1)}$ These days, one of the terrifying cancer types for women around the world is breast cancer. It was estimated around 1.67 million new cases of breast cancer that were diagnosed in 2012 and it became the first rank in the world among the total prevalence of cancer (25\% of all cancer types). ${ }^{(2)}$

According to The Indonesian Society of Surgical Oncology (I.S.S.O), the main management/treatment for cancer includes surgery, radiotherapy, chemotherapy, and hormone therapy. ${ }^{(3)}$ The treatment of cancer should be holistic or comprehensive. The palliative care is used as the approach for solving the encountered problems related to the disease that can harm people's life through preventive actions and relieving pain through early identification, good examination, and therapy for relieving pain, physique, psychosocial, and spiritual. ${ }^{(4)}$

Patients need family support to create a good quality of life. Family support that can be given to the patients can be in the form of an instrumental, award, informational, and emotional support.

The research by Subriah Hidayati shows that there is a significant relationship between family support and quality of life in cervical cancer patients. The frequency of poor family support is $46.7 \%$ and the frequency of good family support is $53.3 \%$, meanwhile, the frequency of poor quality of life in patients is $43.3 \%$ and the frequency of good quality of life in patients is $56.7 \% .^{(5)}$ 
The respondents with poor family support will increase the possibility of having a poor quality of life 8.2 times higher after being controlled using other variables. ${ }^{(6)}$

\section{Purpose}

The purpose of this research is to find out the relationship between family support and quality of life in breast cancer patients at the Chemotherapy Unit of RSUD Abdul Wahab Sjahranie Samarinda.

\section{METHODS}

\section{Research Design}

This research used a quantitative method with analytical study and cross-sectional design which aims to determine the relationship between independent and dependent variabels that were identified at one time.

\section{Research Setting and Time}

This research was conducted from June 12 to July 31, 2019. It was located at the chemotherapy unit of RSUD Abdul Wahab Sjahranie Samarinda.

\section{Population and Sample}

The population of this research was all breast cancer patients at the Chemotherapy unit of RSUD Abdul Wahab Sjahranie Samarinda. This, research used total sampling as the technique. The total sample of 76 respondents was collected from June 12 to July 31, 2019.

\section{Data Analysis}

This research used a family support instrument adopted from a previous questionnaire that was researched by Putra, which has been modified and tested for validity and reliability, and the Quality of Life Questionnaire-Core 30 (EORTC QLQ-C30) for quality of life. Participants were given a questionnaire consisting of a number of Likert scales.

The data that had been collected were analyzed by identifying the frequency distribution such as age, religion, educational background, length of disease, family support, and quality of life. The bivariate analysis was done by using the chi-square test with a significance level $\alpha=0.05$, to find out the relationship between the two variables that were between family support and quality of life.

\section{RESULTS}

\section{The Frequency Distribution of the Respondents based on Characteristics}

Based on the age group, nearly half of the total or 32 respondents $(42.1 \%)$ were the early elderly (46-55 years old). Meanwhile, the remaining or 1 respondent (1.3\%) was early adulthood (26-35 years old). Based on the religion, early all of the respondents or 69 respondents were Moslems $(90.8 \%)$ and the remaining or 7 respondents were Christians (9.2\%). Based on the educational background, it was found out that around half of the total respondent was Elementary graduates. They were 21 respondents in total (27.6\%). Meanwhile, the remaining or 1 respondent $(1.3 \%)$ was a Diploma graduate.

Furthermore, according to the length of disease, it was found out that around half of the total respondents or 35 respondents $(46.1 \%)$ were 1-3 years. Besides, only 1 respondent (1.3\%) who suffered from cancer for more than 5 years. 


\section{The Frequency Distribution of the Respondents based on Family Support}

Table 1 shows the frequency distribution of the respondents based on family support. The table shows that most of the respondents or 42 respondents $(55.3 \%)$ have good family support and nearly half of the total respondents or 34 respondents $(44.7 \%)$ were categorized as less.

Table 1. Distribution of family support

\begin{tabular}{ccc}
\hline Family support & Frequency & Percentage \\
\hline Less & 34 & 44.7 \\
Good & 42 & 55.3 \\
\hline
\end{tabular}

The Frequency Distribution of the Respondents based on Quality of Life

Meanwhile, table 2 shows the frequency distribution of the respondents based on the quality of life. It shows that most of the respondents or 41 respondents $(53.9 \%)$ have a good quality of life and nearly half of the total respondents or 35 respondents $(46.1 \%)$ have a less quality of life.

Table 2. Distribution of quality of life

\begin{tabular}{ccc}
\hline Quality of life & Frequency & Percentage \\
\hline Less & 35 & 46.1 \\
Good & 41 & 53.9 \\
\hline
\end{tabular}

\section{The Relationship between Family Support and Quality of Life in Breast Cancer Patients}

The result of the analysis that is done using the chi-square test obtains a $p$-value of 0.003 , indicating that based on the statistic, there is a relationship between family support and quality of life in breast cancer patients at the chemotherapy unit of RSUD Abdul Wahab Sjahranie Samarinda. From the result of the analysis, it has been obtained an OR value of 4.090, indicating that the patients with less family support have a risk of 4.090 times bigger and it results in a less quality of life compared to the patients with good family support.

Table 3. The relationship between family support and quality of life in breast cancer patients

\begin{tabular}{|c|c|c|c|c|c|c|c|c|}
\hline \multirow{3}{*}{ Family support } & \multicolumn{4}{|c|}{ Quality of Life } & \multirow{2}{*}{\multicolumn{2}{|c|}{ Total }} & \multirow{3}{*}{$\mathrm{P}$-value } & \multirow{3}{*}{$\begin{array}{c}\text { OR } \\
(95 \% \mathrm{CI})\end{array}$} \\
\hline & \multicolumn{2}{|c|}{ Poor } & \multicolumn{2}{|c|}{ Good } & & & & \\
\hline & $\mathrm{n}$ & $\%$ & $\mathrm{n}$ & $\%$ & $\mathrm{n}$ & $\%$ & & \\
\hline Less & 22 & 64.7 & 12 & 35.3 & 34 & 100 & \multirow{2}{*}{0.003} & 4.090 \\
\hline Good & 13 & 31.0 & 29 & 69.0 & 42 & 100 & & $(1.565-10.687)$ \\
\hline
\end{tabular}




\section{DISCUSSION}

The main cause of breast cancer is not found yet, however, the basic cause of abnormal growth of cells in the mammary gland.

Aging can be one of the factors of increasing breast cancer risk. It is believed that it occurs because of the effect of hormonal exposure for a long time, especially estrogens and another risk factor that needs more time to induce the occurrence of cancer. ${ }^{(7)}$

This research finding showed that nearly half of the respondents or 32 respondents $(42.1 \%)$ were early elderly (46-55 years old). It is because of the patients who are getting older experience the reduction of performance in body organs and weak immunity. Therefore, the incidence of being infected and being attacked by the ferocity of cancer in patients is increasingly high.

The research finding of the frequency distribution of the respondents based on their religion showed that nearly all of the respondents or 69 respondents (90.8\%) are Moslems. According to research by Giaquinto et al., it is concluded that religion and spirituality related to physique and mental can result in positive test results related to health status. ${ }^{(8)}$

From the result of the interview with the respondents, the respondents were mostly late in finding out and realizing that the breast lump is a symptom of breast cancer. Lacking knowledge about breast cancer was caused by the low educational background of the respondents. They were mostly elementary graduates with a total of 21 respondents $(27.6 \%)$. Education is an internal factor that can affect family support. ${ }^{(9)}$

Another factor that can affect the respondent's quality of life is the length of cancer. The research finding of the characteristic of the respondents based on the length of disease found out that nearly half of the respondents suffered from cancer for around 1 year to 3 years (46.1\%).

The longer the patients undergo the therapy, the better the patients' adaptations are. It is because of the patients have already received health education or required information from the health officer. Meanwhile, in this research, it is found that most of the respondents suffer from cancer for around 1 year to 3 years which indicates that the respondents analyzed in this research are categorized as new patients. Therefore, selfacceptance and adaptation towards cancer in the patients are not good yet.

According to a theory by Bomar, family support is in the form of behavior to provide service performed by the family members, either emotional support (attention, love, and empathy), award support (giving award and feedback), informational support (suggestion, advice, and information) or instrumental support (human resource, financial contribution, and time). Nurchayati state that family support has an important role in the treatment for various chronic diseases. ${ }^{(10,11)}$

This research shows that the quality of life in breast cancer patients at the chemotherapy unit of RSUD Abdul Wahab Sjahranie Samarinda is categorized as good with a total respondent of 41 respondents $(53.9 \%)$. One of the factors that can result in good quality of life in the respondents in this research, besides family support, is that all of the patients undergo the cancer treatment, namely chemotherapy. It is in line with research by Husni et al., stating that quality of life can be affected by various social and medical status. ${ }^{(12)}$

The result of the chi-square test showed that there was a relationship between family support and quality of life in breast cancer patients at the chemotherapy unit of RSUD Abdul Wahab Sjahranie Samarinda.

This research finding is in line with research by Husni et al., stating that there is a relationship between family support and quality of life in breast cancer patients. This hypothesis is proven statistically and it results in an OR value of 14.000 . It indicates that poor family support will risk the quality of life of 14,000 times worse than before. ${ }^{(12)}$

The research by Irawan et al. shows that there is a relationship between family support and the quality of life of breast cancer sufferers at the shelters of cancer "Rumah Teduh Sahabat Iin" in Bandung with a significance value of $0.024<0.05$. ${ }^{(13)}$ Positive family support has a positive impact on the development of one's self-concept, lack of social support from the family will trigger a person to feel himself nt valued as a whole being and feel axcluded from social life and tend to have a negative self-concept. Family support can help the patients to increase their confidence in their ability to undergo self-treatment. The cancer patients who are surrounded by their family and receive much attention from their family members can elicit feelings of safe and comfortable which can make the patients care about themselves. The researcher believes that the feelings of comfortable in patients will occur because of good support such as informational support, emotional support, instrumental support, and award support from their family. ${ }^{(14)}$

\section{CONCLUSIONS}

The total respondent based on their age is nearly half of the total respondents or 32 respondents (42.1\%) and they are categorized as early elderly (46-55 years old), meanwhile based on religion, almost all of the 
respondents or 69 respondents $(90.8 \%)$ are categorized as Moslems. Besides, based on the respondent's educational background, nearly half of the total respondents or 21 respondents $(27.6 \%)$ are elementary graduates and based on the length of disease, nearly half of the total respondents or 35 respondents (46.1\%) suffer from cancer for around 1 year to 3 years.

The frequency distribution of the respondents based on family support is that most of the respondents or 42 respondents $(55.3 \%)$ have good family support, and nearly half of the total respondents or 34 respondents $(44.7 \%)$ have less family support. Besides, the frequency distribution of the respondents based on the quality of life is that most of the respondents or 41 respondents $(53.9 \%)$ have a good quality of life, and nearly half of the total respondents or 35 respondents $(46.1 \%)$ have a less quality of life.

There is a significant relationship between family support and quality of life in breast cancer patients at the chemotherapy unit of RSUD Abdul Wahab Sjahranie Samarinda ( $p$-value $=0.003$ ).

For the next researcher, it is expected to conduct a study by using more respondents and longer duration of research time and including other characteristics that are not investigated yet such as occupation, stage of the disease, and medical history of having cancer in the family.

\section{REFERENCES}

1. World Health Organization. Palliative Care. Geneva: World Health Organization; 2017. Available from: http://www.who.int/mediacentre/factsheets/fs402/en/

2. Iarc. IA for R on CWHO. GLOBOCAN 2012: Estimated Cancer Incidence, Mortality and Prevalence Worldwide in 2012. Globocan; 2012.

3. Anita A. Palliative Care and Quality of Life of Cancer Patients (Perawatan Paliatif dan Kualitas Hidup Penderita Kanker). J Kesehat. 2016.

4. Indriatmo W, Muharyati A, Setiajati A. Relationship Between Family Support and Motivation to Cure Cancer Patients Undergoing Chemotherapy in One Day Care Room Dr. Moewardi Hospital (Hubungan Antara Dukungan Keluarga dengan Motivasi untuk Sembuh Pada Pasien Kanker yang Menjalani Kemoterapi di Ruang One Day Care RSUD dr Moewardi). Surakarta: STIKes Kusumahusada Surakarta; 2015.

5. Hidayati H, Subriah S. Relationship of Family Support with Quality of Life of Cervical Cancer Patients in Ibnu Sina Hospital Makassar Period January-June 2017 (Hubungan Dukungan Keluarga Dengan Kualitas Hidup Pasien Kanker Serviks di Rumah Sakit Ibnu Sina Makassar Periode Januari-Juni 2017). Media Kesehatan. 2018.

6. Sasmita. Factors Affecting the Quality of Life of Breast Cancer Patients in RSUP DR. M. Djamil Padang in 2016 (Faktor yang Mempengaruhi Kualitas Hidup Pasien Kanker Payudara di RSUP DR. M. Djamil Padang Tahun 2016). Padang: Universitas Andalas; 2016.

7. Azamris. Risk Factor Analysis in Breast Cancer Patients at Dr. M. Djamil Hospital, Padang (Analisis Faktor Risiko pada Pasien Kanker Payudara di Rumah Sakit Dr. M. Djamil Padang). Cermin Kedokt. 2006;152:53.

8. Giaquinto S, Sarno S, Dall'Armi V, Spiridigliozzi C. Religious and spiritual beliefs in stroke rehabilitation. Clin Exp Hypertens. 2010.

9. Rahayu SR. Relationship Between Family Knowledge and Family Support in DM Care in Pamongan Village, Guntur District, Demak Regency (Hubungan Antara Pengetahuan Keluarga dengan Dukungan Keluarga dalam Perawatan DM di Desa Pamongan Kecamatan Guntur Kabupaten Demak). 2008. Available from: http://www.digilib.unimus.ac.id

10. Bomar. Pocket Book of Family Nursing (Buku Saku Keperawatan Keluarga). Jakarta: Elex Media Komputindo; 2006.

11. Nurchayati S. Analysis of Factors Related to Quality of Life of Chronic Kidney Disease Patients Underwent Hemodialysis at the Islamic Hospital of Fatimah Cilacap and Banyumas Regional General Hospital (Analisis Faktor-Faktor yang Berhubungan dengan Kualitas Hidup Pasien Penyakit Ginjal Kronik yang Menjalani Hemodialisis di Rumah Sakit Islam Fatimah Cilacap dan Rumah Sakit Umum Daerah Banyumas). Depok: Universitas Indonesia; 2010.

12. Husni M, Romadoni S, Rukiyati D. Relationship between Family Support and Quality of Life of Breast Cancer Patients in Surgical Inpatient Installation, Dr. Mohammad Hoesin Hospital, Palembang in 2012 (Hubungan Dukungan Keluarga dengan Kualitas Hidup Pasien Kanker Payudara di Instalasi Rawat Inap Bedah RSUP Dr. Mohammad Hoesin Palembang Tahun 2012). Jurnal Keperawatan Sriwijaya. 2015.

13. Irawan E, Hayati S, Purwaningsih D. Relationship between Family Support and Quality of Life for Breast Cancer Patients (Hubungan Dukungan Keluarga dengan Kualitas Hidup Pasien Kanker Payudara). Jurnal Keperawatan BSI. 2017.

82 Publisher: Humanistic Network for Science and Technology 
14. Maria IL, Sainal AA, Nyorong M. Lifestyle Risk Factors of Women with Breast Cancer (Risiko Gaya Hidup Terhadap Kejadian Kanker Payudara pada Wanita). J Mkmi. 2017. 